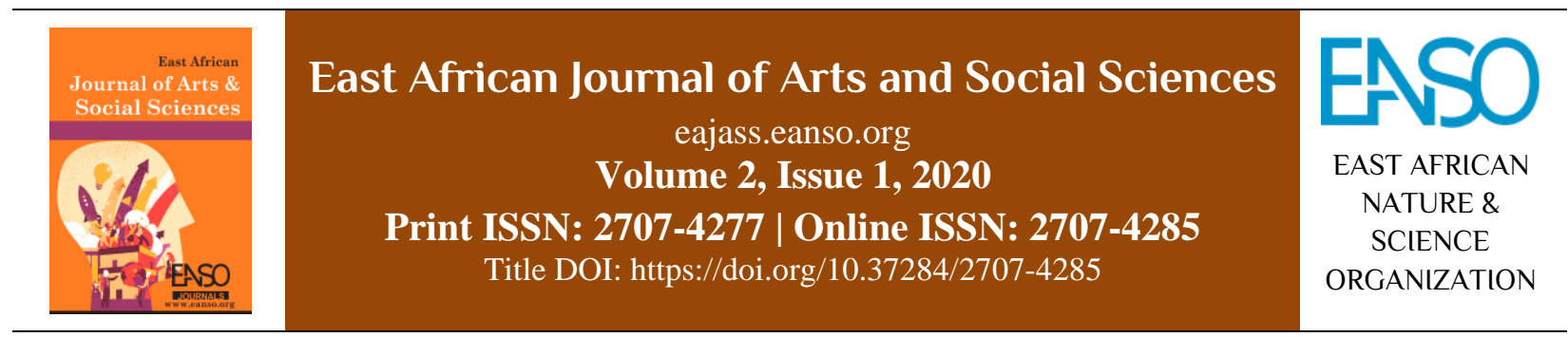

Original Article

\title{
Towards an Authentic Nigeria Hymnody: The Study of Yoruba Hymnody
}

\author{
Marie Agatha Ozah, $P h D^{l} \&$ David Bolaji, $P h D^{1 *}$
}

${ }^{1}$ Department of Music, University of Port Harcourt, Rivers State, Nigeria.

*Author for Correspondence email: erin4david@yahoo.co.uk.

Article DOI: https://doi.org/10.37284/eajass.2.1.202

Article history: ABSTRACT

29 August 2020

Keywords:

Hymnology,

Tonal Inflexion,

Composition,

Yoruba.
The indigenous hymnology has experienced a lot of tonality distortion in Nigeria due to the direct translation of Western hymn tunes to the indigenous hymns.

Different scholars have identified this act of perversion, but little or no documentation can be found on the method(s) that can be used in correcting this perverse act. The focus of this paper is on Yoruba hymnody. In this light, the paper examines and discuss the abnormality found in Yoruba indigenous hymns, through an analytical content of three selected indigenous Yoruba hymns and propounds methods and implementation strategies towards correcting the aforementioned act of perversion. Findings revealed that most of the indigenous hymns had been distorted in meaning due to the deformation of the indispensable Yoruba tone language. The paper discusses and draws out specific lessons that would serve as channels and even methods for consideration during composition, especially by Nigerian art composers. Tackling this challenge from a unanimous perspective, the effort will address the articulation and use of tonal inflexions in Yoruba Nigerian hymns.

\section{APA CITATION}

Ozah, M., \& Bolaji, D. (2020). Towards an Authentic Nigeria Hymnody: The Study of Yoruba Hymnody. East African Journal of Arts and Social Sciences, 2(1), 67-72. https://doi.org/10.37284/eajass.2.1.202

\section{CHICAGO CITATION}

Ozah, Marie, and David Bolaji. 2020. "Towards an Authentic Nigeria Hymnody: The Study of Yoruba Hymnody". East African Journal of Arts and Social Sciences 2 (1), 67-72. https://doi.org/10.37284/eajass.2.1.202.

\section{HARVARD CITATION}

Ozah, M. and Bolaji, D. (2020) "Towards an Authentic Nigeria Hymnody: The Study of Yoruba Hymnody", East African Journal of Arts and Social Sciences, 2(1), pp. 67-72. doi: 10.37284/eajass.2.1.202. 


\section{IEEE CITATION}

M. Ozah and D. Bolaji, "Towards an Authentic Nigeria Hymnody: The Study of Yoruba Hymnody", EAJASS, vol. 2, no. 1, pp. 67-72, Aug. 2020.

\section{MLA CITATION}

Ozah, Marie, and David Bolaji. "Towards an Authentic Nigeria Hymnody: The Study of Yoruba Hymnody". East African Journal of Arts and Social Sciences, Vol. 2, no. 1, August 2020, pp. 67-72, doi:10.37284/eajass.2.1.202.

\section{INTRODUCTION}

Indigenous languages are diverse in nature based on different ethnic groups that make up Nigeria at large. The concept of tonal inflexion cuts across most of the indigenous languages in the country. Nigeria is said to be the largest and overpopulated country in Africa with over 256 ethnic groups with the three major ethnic groups being Yoruba, Igbo and the Hausa. Indigenous vowel sound could be inflected or altered with the same syllable depicting different meaning when altered at different vocal pitches or registers. The penetration of Christian Missionaries into the Nigerian soil brought the issue of converts who were taught western ideals, while the new mode of Christian worship was introduced to the people, especially converts. The effect of this distortion became evident in our society and the general way of life after these missionaries condemned and banned the indigenous way of life and culture including music. This discouragement of attention on traditional cultural heritage engendered a lack of continuity in our traditional activities. Omibiyi (1975) buttress this issue noting that the musical tradition of a society can be seen through its cultural heritage.

\section{GENERAL INFLUENCE OF TONAL LANGUAGE}

Idamoyibo (2006) and Arom (1991) suggested that music and language are closely interconnected and that the phonemic structure of language has a powerful constraining effect on the melodic structure of the songs. Also, Arom (1991) affirmed that since word and music are intimately linked together, the tonal language are themselves coded with meaning and each syllable has its own pitch, intensity and duration to which may be assigned a musical notation (pitch and note). At the same time, Idamoyibo (2006) asserts that the act of consideration of song from the point of view of its contextual device and its tonal structure gives a thorough musical explanation of its form that serves as the contextual way of examining the tonal structure of the language in which it is rendered. This concept is based on the analytical context at different levels of movement in intervals, which depends on the rhythmic segment of the traditionally acceptable tones.

\section{The Effect and Contribution of Western Education in Nigeria}

The introduction of British Colonial Administration and Christian Missionary on the coastland of Nigeria in the mid-nineteenth century had a strong influence on the governing system, belief system, and mode of worship in Nigeria. Among the early Christian Missionaries that came into Nigeria were Catholic missionaries, C.M.S, Anglican Communion, Methodist and the Baptist Missionaries. With this influx also came the Western system of education that served as a major avenue and tool for penetrating the country by the colonial master. This strong tool (education) paved the way for an erosion that swept off most of our cultural heritage in Nigeria. The first Western educational school was established by the Methodist Church, but the CMS Missionaries made a large and more significant contribution to the growth of the Western educational system. Vidal (2012) stated that:

In 1814, the Wesleyan missionaries visited Badagry and reached Abeokuta in 1846 (Burns, 
1972). The Church Missionaries Society (CMS) landed later in Badagry in 1843 with Rev. $H$. Towsend. The first divine service by the CMS was held in Abeokuta town on January 5, 1853, while the first CMS Baptist was held on February 5, 1848, Rev. D. Hinderer visited Lagos. Between 1841 and 1902, EuroChristian religious and cultural influences swept through the southern part of Nigeria and brought with them the importation of Christian religious music from Europe.

The Northern part of the country was not left out as their cultural heritage also came in contact with Islam, which brought a lot of changes to their culture including dressing, mode of worship and general way of life to mention but few. The western region of Nigeria experienced an early form of education than the Northern part of the country due to early contact with the Western world. Generally, indigenous religion and traditional music in Nigeria witnessed a turnaround as the result of these contacts. Specifically, the use of indigenous music along with the traditional musical instruments were discouraged and even eradicated by the missionaries for the reason that Indigenous music in Nigeria had no relationship or attachment to the spiritual realm. As a result of this condemnation, the use of indigenous music and musical instrument was banned in Church worships.

The obliteration of unknown authorship song that is folk songs came broadly. To a large extent singing of folk tunes was discouraged by Western Missionaries, while Western hymns and chants were introduced to replace the indigenous songs. In order to inculcate these Western religious views on the Nigerians, converts were given free Western educational training, which led some to be school teachers and Sunday school teachers alongside with some skill acquisition works. Some of these converts were even taught how to play Western musical instruments - piano and organ that replaced their indigenous instruments. Some of the converts who were very good on these instruments were even sent abroad to study. As the Western hymns and chants replaced the indigenous folk songs, the act of playing a Western musical instrument was inculcated into the mode of worship as a major accompanying musical instrument during hymns singing during religious worship (Service and Mass). The Western model of service eventually dominated the indigenous mode of worship and hymn singing became the major song type during moments of worship.

That said, a number of Nigerians were converted to Christianity, which gave the Western world the upper hand in completely changing the belief system of their converts. For effective and proper worship in various Churches/Service Centres established by the missionaries, a direct translation of Western hymns were done in various Nigerian languages, most prominently in the Yoruba and Igbo languages. Just as the hymns were being translated, so also was the translation of the bible from English into the Nigerian languages. This translation of English hymns into the Nigerian indigenous languages posited some composition and textual issues some of which this paper will attempt to address with a focus on Yoruba hymnody.

\section{YORUBA HYMNODY}

Basically, in traditional Yoruba music, the melodic patterns (contour) often reflect the tonal inflexion and speech rhythm of words so that the correct meaning of the words are pronounced correctly and musically articulated. But this was not the case when the European hymn tunes directed translated into the Yoruba language. The translation and thus improper articulations of the texts swept off the tonal inflexion of the Yoruba text. This experience resulted in a complete distortion of Yoruba tonal language. An agitation arose when some of the earliest Nigerian Art musician, that had Western knowledge of music, began to see a great need to guard against the total distortion of the Yoruba tonal language in music. This set of scholars began 
to compose new tunes and adapted folk song tunes to replace the Western tunes used in singing Yoruba text.

\section{Early Contribution of Some Yoruba Art Composers}

Some individual music enthusiasts and musicians have contributed a lot to Yoruba indigenous hymnology; specifically making sure that the speech and tonal inflexion of the language are properly articulated in the Yoruba musical composition. According to Omojola (1995), Emmanuel Sowande and Rev. J. J. Ransome Kuti contributed immensely to the Yoruba sacred song, while A. T. Ola Olude composed songs that are compiled together in a book titled Mayo Kun. Also, T. K. E. Phillips, Akin George and Bola Fadeyi all composed songs that are found in a compilation titled, Imole Okan while Oluyemi Olaniyan composed songs compiled together in a book titled Orin Ijosin.
Yoruba
Tones
1. /I-gba/
(low -low tones) meaning
(mid - low tones) meaning
(mid-low-high tones) meaning
(high-high tones) meaning
2. /I-gba/
3. /I-gba/
4. /I-gba/

English Meaning
Season
200 in number
Guarding eggs
Calabash
English Meaning
Season
Guarding eggs depending on how syllables are intoned. example, from the di-syllabic Yoruba morpheme /I$\mathrm{gba} /$, different meanings may be intended

\section{ANALYSIS OF SOME YORUBA HYMNS}

As earlier observed, the Western style of songs and singing have a strong effect on the melodic line of most Yoruba hymns. It is thus pertinent to examine and analyse some selected Yoruba hymns that were a direct translation of European hymns.

\section{Example One: Take My Life and Let It Be (Written by Francis Havergal)}

GBA AIYE MI OLUWA

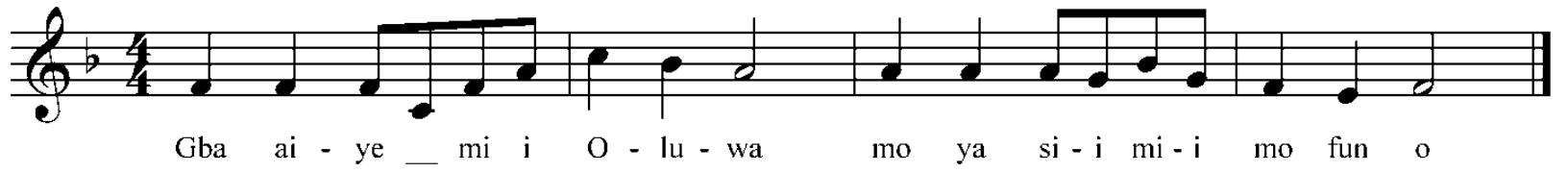

English

Take my life and let it be consecrated Lord to thee, Take my hands and let them move at thy love, At the impulse of thy love
Yoruba

Gba aiye mi Oluwa mo ya si mimo fun o Gba gbogbo akoko mi ki won kun fun iyin re Ki won kun fun iyin re 
The English text of the above hymn tune goes perfectly in line with the melody and the proper accentuation of the text. However, in the Yoruba context, when this hymn is translated directly into the Yoruba language, the melody ceases to follow the correct rising and falling of tonal inflexion of the Yoruba language, thus changing the meaning of the text. That is to say, the correct meaning of the song is displaced from the context of its real meaning. For the hymn to be relevant in meaning to enable the worshipers to appreciate the text, the authors suggest the melodic line below that articulates the inflexion of the Yoruba language:

Suggested Tune

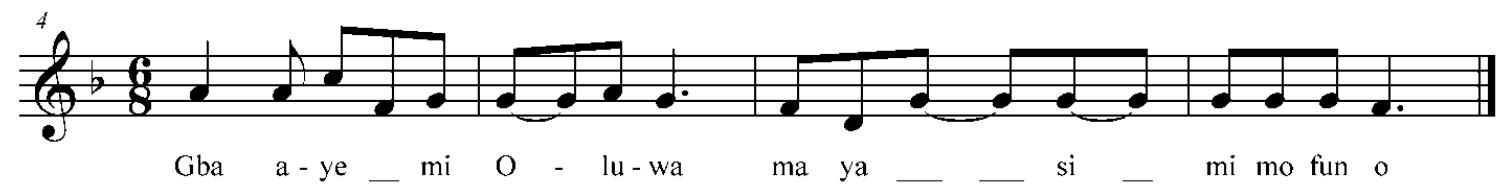

Example Two: Onward Christian Soldiers (Composed by Arthur Sullivan 1871)

English

Onward Christian Soldier, marching as to war, with the cross of Jesus going on before;

Christ, the royal master,

leads against the foe forward into battle see his banner go.
Yoruba

E ma tesiwaju, kristian Ologun

Ma tejumo Jesu t'O mbe niwaju

Kristi Oluwa wa ni Balogun wa,

Wo! Asia Re wa niwaju Ogun,
As with the first example above, the texts of this hymn turn correspond with the melodic line, which reflected the correct English meaning of the song. But the reverse is the case when the same turn was imposed on the Yoruba text without considering the tonal inflexion of the language. Consequently, the incorrect meaning of the song in Yoruba emerges as follows:

Keep laying it in front, Christian that is shoulders, Keep looking at Jesus who is in front

Example Thee: O Come All Ye Faithful (By John Francis Wade 1711 - 1786)

\section{English}

O come all ye faithful, joy-full and triumphant, O come, O come ye to Bethlehem, come and behold him, born the king of angels!

\section{$\underline{\text { Yoruba }}$}

Wa eyin olooto, Layo ati 'segun

Wa kalo, wa kalo si Betlehemu

W aka lo wo o! Oba awon Angeli!
But the direct translation of the same tune to Yoruba gives it a different meaning entirely. The wrong meaning goes by:

Pack the back of palm kennel o you bed water... (can you complete the translation of the wrong text?)

\section{Dynamic Approach/Correct Methods}

Basically, Hymns/songs in African (Nigerian) tone languages should be introduced into our primary and secondary schools to enable the young pupils to appreciate them. This approach will help the concept of tone language to be imbued in the child at an early age. Although this is already in progress in some higher institutions of learning, young composers should be taught and encouraged the effective use of tonal inflexion in the indigenous 
languages of Nigeria. Granted that the Western Missionaries had little or no other ways of bringing their Western hymns to the new converts, modernday church musicians should strive to adhere to the tonal inflexion of their indigenous language while composing hymns for the Church of today. This concept/approach will surely help the younger generation to understand the act of writing using the tone language.

Exchange of compositional techniques and compositions in the different Nigerian languages during conferences will re-emphasise this concept both at the local and national level. By so doing, not only will new and effective hymns/songs be used during Church services, it will aid in preserving aspects of our cultural heritage for the future generation. Furthermore, to help both the choir and the entire congregation on the issue of correct use of tonal inflexion, choirmasters, organist and music directors should emphasise the use of indigenous hymn books during services in their various denominations.

\section{CONCLUSION}

The above study has briefly reviewed and contextualised the major roots of distortion of Nigerian, specifically Yoruba, the tonal language in Church hymn tunes. The article further shows the differences and creative links between Western and African musical elements. A common practice of the use of native tunes in Christian worship came into existence in the late 1950s in Nigeria. Although one can sometimes find hymns composed in the vernacular that do not adhere to the tonal inflexion of the language, more composers are becoming aware of this mistake. It is hoped that this article will add the call to this consciousness; thus, engendering compositions with correct indigenous language inflexions and paving the way for effective and more spiritually sensed Christian worship.

\section{REFERENCES}

Akinwumi, D. (1987). Yoruba composition for S. A. T. $B$.

Arom, S. (2004). African polyphony and polyrhythm: musical structure and methodology. Cambridge university press.

Bankole, A. (1970). Three Yoruba songs for baritone. Ife music Editions No 6.

Bankole, A. (1975). Three parts song for female choir. Ife music Editions No. 3.

Idamoyibo, A. A. (2006). Yoruba traditional music in Christian worship: A case study of Ijala Musical Genre. Unpublished $\mathrm{PhD}$ Thesis. University of Ibadan.

Idamoyibo, I. O. (2006) Igoru music in Okpeland, A study of its functional and compositional techniques. Unpublished $\mathrm{Ph}$. D. Thesis. University of Pretoria South Africa.

Olaniyan, O. (n.d.). Orin Ijosin. Famority Printing Press Itesa.

Olude A. T. O.(undated) Mayokun Lagos: tikaTore press Ltd.

Omibiyi, M. (1975). The Training of Yoruba Traditional Musicians. In Abimbiola, W. (Eds), Yoruba Oral Traditional: Poetry in Music, Dancke and Drama (pp. 489 - 516). Ife: University of Ife.

Omojola, B. (1995). Nigeria Art Music. Ibadan: Institute of Franchaise De Recherche De Afrique (IFRA).

Vidal, O. (2012). 'The Westernization of African Music: A Study of Yoruba Liturgical Church Music' in Essays on Yoruba Musicology: History, Theory and Practice edited by Femi Adedeji, 24 - 36. Ile Ife: Obafemi Awolowo University Press. 